Chapman University

Chapman University Digital Commons

Education Faculty Articles and Research

Attallah College of Educational Studies

2018

\title{
Paulo Freire and Liberation Theology: The Christian Consciousness of Critical Pedagogy
}

Peter McLaren

Chapman University, mclaren@chapman.edu

Petar Jandrić

Zagreb University of Applied Sciences

Follow this and additional works at: https://digitalcommons.chapman.edu/education_articles

Part of the Christianity Commons, Curriculum and Social Inquiry Commons, Educational Leadership Commons, Educational Methods Commons, Liberal Studies Commons, Other

Education Commons, Other Religion Commons, Religious Thought, Theology and Philosophy of

$\underline{\text { Religion Commons, and the Social and Philosophical Foundations of Education Commons }}$

\section{Recommended Citation}

McLaren, P., and Jandrić, P. (2018). Paulo Freire and liberation theology: The Christian consciousness of critical pedagogy.

Vierteljahrsschrift für wissenschaftliche Pädagogik, 94(2), 246 - 264. doi: 10.30965/25890581-09402006

This Article is brought to you for free and open access by the Attallah College of Educational Studies at Chapman University Digital Commons. It has been accepted for inclusion in Education Faculty Articles and Research by an authorized administrator of Chapman University Digital Commons. For more information, please contact laughtin@chapman.edu. 


\section{Paulo Freire and Liberation Theology: The Christian Consciousness of Critical Pedagogy}

\section{Comments}

This article was originally published in Vierteljahrsschrift für wissenschaftliche Pädagogik, volume 94, issue 2, in 2018. DOI: $10.30965 / 25890581-09402006$

\section{Copyright}

Brill 


\section{Paulo Freire and Liberation Theology: The Christian consciousness of critical pedagogy ${ }^{1}$}

Peter McLaren (Chapman University, U.S.) \& Petar Jandrić (Zagreb University of Applied Sciences, Croatia)

\section{Introduction}

Peter McLaren is one of the founding members of the contemporary critical pedagogy movement and close collaborator and friend with other key figures including Paulo Freire, Henry Giroux, and Donaldo Macedo. Peter's canonical books, such as best-selling Life in Schools: An Introduction to Critical Pedagogy in the Foundations of Education (1989, 6 ${ }^{\text {th }}$ edition 2014), have defined critical pedagogy as we know it today. As the key force behind its shift from postmodernism to humanist Marxism (Jandrić, 2017: 160), Peter has put the word revolutionary into the tradition of critical pedagogy.

At the brink of the millennium, development of critical pedagogy has slowed down. Commenting on its perceived lack of vitality, Derek Ford writes: "My position is that critical pedagogy is at a dead-end. This is not to say that it offers nothing valuable, but rather that it is been stagnant for some time (I would say at least since the beginning of the 21st century)" (Ford, 2017: 2). However, Ford's position simply does not apply to Peter McLaren. In 2015, Peter published the ground-breaking book Pedagogy of Insurrection: From Resurrection to Revolution (McLaren, 2015) which reinvents the late $20^{\text {th }}$ century Latin American tradition of critical pedagogy in the Marxist context of revolutionary critical pedagogy. With Pedagogy of Insurrection, Peter has once again shaken the established borders of the tradition and iconoclastically developed revolutionary critical pedagogy into pastures new and unexplored.

\footnotetext{
${ }^{1}$ Peter McLaren's 's writings on Paulo Freire are very extensive. Some of the answers to my questions were taken directly from some of Peter's previous writings which he sent to me, and some of Peter's remarks have also been excerpted from previous dialogues we have had on the topic of liberation theology.

Extracts from Peter's previous writings on Freire used in some sections of the dialogue originally appeared in the following publications: McLaren, P. (1997). Paulo Freire died May 2, 1997. International Journal of Educational Reform, 6(3): 263-256, McLaren, P. (2000). Che Guevara, Paulo Freire, and the pedagogy of revolution. Boulder, CO: Rowman \& Littlefield, McLaren, P. (2011). Afterword: Paulo Freire: Defending His Heritage to Remake the Earth. In J. D. Kirylo, Paulo Freire: The Man from Recife. New York: Peter Lang, 305-320.

Extracts from previous dialogues between Peter and Petar used in some sections of this text originally appeared in the following publications: McLaren, P. \& Jandrić, P. (2017). From Liberation to Salvation: Revolutionary critical pedagogy meets liberation theology. Policy Futures in Education, 15(5), 620-652, McLaren, P. \& Jandrić, P. (2017). Peter McLaren's Liberation Theology: Karl Marx meets Jesus Christ. In J. S. Brooks and A. Normore (Eds.), Leading Against the Grain: Lessons for Creating Just and Equitable Schools. New York: Teachers College Press, 39-48, McLaren, P. \& Jandrić, P. (2018). Karl Marx and Liberation Theology: Dialectical materialism and Christian spirituality in, against, and beyond contemporary capitalism. TripleC: Communication, Capitalism \& Critique.
} 
In 2014-2015 Peter and I have co-written several dialogical texts on the digital challenge of critical pedagogy (McLaren and Jandrić, 2014, 2015a, 2015b; Jandrić, 2017). After Pedagogy of Insurrection (2015), we published a few more conversations on development of Peter's liberation theology beyond his book (McLaren and Jandrić, 2017a and 2017b) and more specifically on the relationships between liberation theology and Marxism (McLaren and Jandrić, 2018). In this article we expand our work towards intersections and relationships between liberation theology and Paulo Freire. While Freire addressed liberation theology in his writings fairly sporadically (e.g. The Politics of Education, [1985]), there is no doubt that he "lived a liberating Christian faith" and "significantly contributed to the thinking of liberation theology" (Kyrilo, 2011: 167). Now that Paulo Freire is no longer with us, arguably the best way to reinvent his works for the present moment is through dialogue with Peter McLaren: Freire's his close friend, "intellectual relative” (Freire, 1995: X), and one of the key forces behind contemporary developments in liberation theology.

\section{The life and work of Paulo Freire}

Petar Jandrić (PJ): Please say a few words about the life and work of Paulo Freire.

Peter McLaren (PM): Paulo Reglus Neves Freire was born on September 19th, 1921 in Recife, in the Northeast of Brazil. As a courageous and humble scholar, social activist, and cultural worker, Freire was able to develop an anti-imperialist and anticapitalist literacy praxis that served as the foundation for a more broadly based struggle for liberation. In his first experiment in 1963, Freire taught 300 adults to read and write in 45 days. This method was adopted by Pernambuco, a sugar cane-growing state 1,160 miles northeast of Rio. This success marked the beginning of what was to become a legendary approach in education.

Freire's internationally celebrated work with the poor began in the late 1940s and continued unabated until 1964, when a right-wing military coup overthrew the democratically elected government of President João Goulart. Freire was accused of preaching communism and arrested. He was imprisoned by the military government for seventy days and exiled for his work in the national literacy campaign, of which he had served as director. According to Moacir Gadotti, the Brazilian military considered Freire "an international subversive," "a traitor to Christ and the Brazilian people" and accused him of developing a teaching method "similar to that of Stalin, Hitler, Peron, and Mussolini." He was furthermore accused of trying to turn Brazil into a "Bolshevik country" (1994).

Freire's 16 years of exile were tumultuous and productive times: a fiveyear stay in Chile as a UNESCO consultant with the Research and Training 
Institute for Agrarian Reform; an appointment in 1969 to Harvard University's Center for Studies in Development and Social Change; a move to Geneva, Switzerland in 1970 as consultant to the Office of Education of the World Council of Churches, where he developed literacy programs for Tanzania and Guinea-Bissau that focused on the re-Africanization of their countries; the development of literacy programs in some postrevolutionary former Portuguese colonies such as Angola and Mozambique; assisting the government of Peru and Nicaragua with their literacy campaigns; the establishment of the Institute of Cultural Action in Geneva in 1971; a brief return to Chile after Salvador Allende was assassinated in 1973, provoking General Pinochet to declare Freire a subversive; his brief visit to Brazil under a political amnesty in 1979; and his final return to Brazil in 1980 to teach at the Pontificia Universidade Catolica de Sao Paulo and the Universidade de Campinas in Sao Paulo. These events were accompanied by numerous works, most notably Pedagogy of the Oppressed (Freire, 1972), Cultural Action for Freedom (Freire, 1970) and Pedagogy in Process: Letters to Guinea-Bissau (Freire, 1978). In more recent years, Freire worked briefly as Secretary of Education of Sao Paulo, continuing his radical agenda of literacy reform for the people of that city.

Based on a recognition of the cultural underpinnings of folk traditions and the importance of the collective construction of knowledge, Freire's literacy programs for disempowered peasants are now employed in countries all over the world. By linking the categories of history, politics, economics, and class to the concepts of culture and power, Freire has managed to develop both a language of critique and a language of hope that work conjointly and dialectically and which have proven successful in helping generations of disenfranchised peoples to liberate themselves.

PJ: Please say more about Freire's famous approach to literacy. Back in the day, why was it considered so dangerous?

PM: Freire's literacy method grew out of the Movement for Popular Culture in Recife that had set up "cultural circles" (discussion groups with nonliterates) by the end of the 1950s. Freire believed that the oppressed could learn to read provided that reading was not imposed upon them in an authoritarian manner and that the process of reading validated their own lived experiences. After all, adults could speak an extraordinarily rich and complex language but lacked the graphical skills to write their ideas down. Freire understood that alienated and oppressed people are not heard by the dominant members of their society. The "culture of silence" that we created by the dominant culture did not mean that the oppressed could not respond to their own reality but that such a response often lacked a critical dimension.

In the "circulo de cultura" educators and learners employed codifications to engage in dialogue about the social, cultural and material conditions that impacted their lives on a daily basis. In the cultural circle, the peer group played a crucial role by providing the theoretical context for reflection and by 
transforming interpretations of reality from the production of 'everyday commonsense' to a more critical knowledge.

Freire and his colleagues spent considerable time in cultural circle settings with people from the local communities, making a list of the words used, the expressions, the informal jargon, and the characteristic mannerisms that accompanied certain phrases in order to gain an understanding of the 'cultural capital' of the people. Such topics as nationalism, development, democracy, and illiteracy were introduced through the use of slides or pictures, followed by a dialogue. The words "codified" the ways of life and the lived experiences of the local community members. Codifications included photographs, drawings, or even words, since they were all representations that permitted extended dialogue and an analysis of the concrete reality represented. Codifications mediated between the everyday lived experiences of the people and the theorizing that took place related to the context of everyday life. Codifications also mediated between the educators and learners who were actively engaged in coconstructing the meanings of their daily existence. In this way, Freire's approach to literacy brushed against the grain of mainstream literacy methods that required individuals to learn the words and ideas from books or materials that were produced by those in power. To learn to read from a primer meant that learners must accept the experiences inscribed in the primer as more important than their own. Freire was able to identify generative themes that permeated the experiences of those who believed the current conditions of their existence such as poverty and illiteracy - were due to fate, or to chance, or to their own constitutive inferiority, yet who desired so much to become literate. Freire recognized that oppressed learners had internalized profoundly negative images of themselves (images created and imposed by the oppressor) and felt incapable of taking an active participation in their own affairs.

PJ: How did Freire's approach to literacy work in practice?

PM: The generative themes that Freire was able to elicit from his time spent with the oppressed were codifications of complex experiences that had a great deal of social meaning and political significance for the group and were likely to generate considerable discussion and analysis. They were selected because they derived from the contextual specificity of the history and circumstances of the learners, but they were also chosen for their syllabic length and with the goal of presenting all the phonemes of the Portuguese language. Freire's 'method' (Freire's work can't be reduced to a method strictly speaking, since it is more of a political philosophy) consisted of an investigative stage of finding the words and generative themes of a group in terms of their social class relevance and meaning for that group. Generative themes were often codified into generative words - more specifically, tri-syllabic words that could be broken down into syllabic parts and used to "generate" other words (Brown, 1987). Freire and his culture circles practiced a form of decodification that broke up a codification into its constituent elements so that the learners began to 
perceive relationships between elements of the codification and other experiences in their day-to-day lives. Such decodification took place through dialogue, in which familiar, everyday experiences were made strange and the strange or unknown process of generating critical knowledge was made familiar.

Freire followed the creation of generative themes with the process of thematization, where generative themes were codified and decodified and replaced by a critical social vision. New generative themes were then discovered and instructors were able to breakdown and identify phonetic groups at this stage. This was followed by problematization (the antithesis of problem-solving) that consisted of codifying reality into symbols that could generate critical consciousness. During the problematization stage, the group within the cultural circle examined the limits and possibilities of the existential situations that emerged from the previous stage. Critical consciousness demanded a rejection of passivity and the practice of dialogue. Critical consciousness was brought about not through an individual or intellectual effort, but through conscientization or identifying contradictions in one's lived experience, and understanding and overcoming dominant myths, traditions, and ideologies in order to reach new levels of awareness of being an "object" in a world where only "subjects" have the means to determine the direction of their lives. The process of conscientization involved becoming a "subject" with other oppressed subjects and taking part in humanizing the world through collective struggle and praxis. Conscientization involved experiencing oppressive reality as a process that can be overcome through transformative praxis. Such a praxis (a cycle of action-reflection-action) involved overcoming through concrete actions and group effort those obstacles to the process of becoming human (Gadotti, 1994). Freire's approach to literacy created the conditions for the oppressed to liberate themselves and, in the process, liberate their oppressors. See the excellent summary of Freirean literacy methodology by Cynthia Brown (1987).

PJ: You are too humble, Peter - your own books, such as Che Guevara, Paulo Freire, and the pedagogy of revolution (McLaren, 2000), are amongst the richest sources on Paulo Freire! But let us move on: Please link Freire's approach to literacy with his understanding of knowledge.

PM: Freire was one of the first educational philosophers to underscore repeatedly the concept of "knowing" as a political act. One way of examining knowledge that is highly indebted to the ideas of Freire is to see educators as working within the intersection of temporality and narrative as a dialectical event. Here, experience, temporality, reflection and social action come together in what is commonly referred to in Freirean discourse as "praxis." In the field of anthropology, the profane or historical time of contemporary social groups (involving the concreteness, linearity and irreversibility of time) is often juxtaposed with the mythical time of so-called archaic societies (time that repeats paradigmatic or archetypal gestures that are filled with deep meaning for the participants who use such recurrent mythical forms as a prism for 
personhood). Freire's notion of praxis, however, brings both conceptions of time into the narrative fabric of the emergent self.

The act of knowing is grounded in a type of mythopoetic desire (a desire to raise our own existence to a level of greater meaningfulness; see Freeman, 1998) linked to community, to a new level of sacred authenticity, to organizing life in imaginatively new ways that refuse to reproduce the alienation and objectification necessarily found in the world of abstract labor. Here, revolutionary praxis folds historical and mythical time into an act of negating what is, in anticipation of what could be. Schematically put, the line (the perpetual reappearance of the present in historical time) is folded into the circle (the primordial horizon of the irredeemably configured past).

One of Freire's goals is becoming conscious of and transcending the limits in which we can make ourselves. We achieve this through externalizing, historicizing and objectifying our vision of liberation, in treating theory as a form of practice and practice as a form of theory as we contest the psychopathology of everyday life incarnate in capitalism's social division of labor. We do this with the intention of never separating the production of knowledge from praxis, from reading the word and the world dialectically (Stetsenko, 2002). In so doing we maintain that practice serves as the ultimate ground for advancing and verifying theories as well as for providing warrants for knowledge claims. These warrants are not connected to some fixed principles that exist outside of the knowledge claims themselves but are derived by identifying and laying bare the ideological and ethical potentialities of a given theory as a form of practice (ibid.). Critical educators seek to uncover what at first blush may appear as the ordinary, transparent relations and practices that make up our quotidian existence - what we might even call mundane social realities. We take these relationships and practices and try to examine their contractions when seen in relation to the totality of social relations in which those particular relations and practices unfold. Such an examination takes place against a transdisciplinary backdrop that reads the word and the world historically.

PJ: Back in the day, Freire's work profoundly shaped the landscape of education. What about its contemporary legacy?

PM: Freire's work has had a strikingly significant impact on the genesis and ongoing development of the field of critical pedagogy. Critical pedagogy is constituted by a body of theory associated with Freire's work and critical social theory more generally that emphasize praxis. The field of critical pedagogy has recently expanded its purview to include revolutionary critical pedagogy, an attempt to reclaim Freire's Marxist epistemological roots through the development of a philosophy of praxis driven primarily by the work of Marx and Hegel. Freire's research has been felt in the fields of theology, literacy, composition studies, literary studies, applied linguistics, sociology, 
anthropology and political philosophy. That his work has cross-fertilized so many areas of research is a testament to its transdisciplinary reach.

PJ: One of the main strengths of Freire's work is its versatility. His legacy constantly (re)appears in radically different contexts and situations, and Pedagogy of the Oppressed (Freire, 1972) is the third most cited book in the history of the social sciences (Green, 2016). Comprehending such diversity is beyond human means, so it's worth asking: What, for you, is the essence of Freire's work?

PM: It was my privilege to have witnessed Freire walking among us, laughing and light-footed, his tiny shoulders heaving like twin turbines beneath his crisp, freshly starched shirt, his slender legs gliding with a carefree, insouciant lilt, as if he were being helped along by a puckish breeze that served as a counterpoint to his steady, almost relentless gaze. To me, it seemed as though he was always peering into the present somewhere from the future, in some future anterior where dreams are on a collision course with what is occurring in the laboratories of everyday life we call reality, where light breaks through dark chambers that cannot be illuminated without love. To understand that collision is to understand the essence of Freire's work. Without a careful reading of Freire's intellectual roots, one can only witness the collision without understanding the systems of intelligibility that make such a collision inevitable and without understanding the possibilities of sublating such a collision in order to bring about alternative futures linked to the sustainability of the planet and humanity as a whole. This is the grand mysterium of Freire's work.

\section{Paulo Freire and liberation theology}

PJ: After publication of Pedagogy of Insurrection (McLaren, 2015), liberation theology has slowly but surely resurfaced in the discourse of (revolutionary) critical pedagogy. What is the main point of convergence between Freire and liberation theology?

PM: Freire was a Christian and sympathetic to Marx, and while I never had a chance to discuss with Paulo the topic of liberation theology, I believe that it would have been a fascinating dialogue. For me, critical consciousness is something that is central to the movement of liberation theology. In the sense that Christians come to recognize not only their preferential option for the poor but, as I would put it, their preferential obligation and commitment to the poor. Critically conscious Christians do not only come to recognize their political formation as subjects - their standpoint epistemology - in relation to others, but also gain ontological and ethnical clarity on their role as Christians.

PJ: It's a shame that you and Freire never discussed liberation theology, yet we can still discuss liberation theology in relation to Freire's work. But first things first: What is liberation theology; under which circumstances did it develop? 
PM: Liberation theology was born out of the self-theologising of radical Catholic Action communities in America Latina. There were protestant variants as well; since the 1960s, many variants of liberation theology have emerged such as Jewish Liberation theology, Black Liberation Theology, Feminist Liberation Theology, and Latino/a Liberation Theology. Liberation theology is systematically opposed to the trenchant conservative politics of white evangelical America in the U.S. who encourage individual charity over economic and transformation and distributive social justice so familiar to many living in the richest country in the world. There arose among both lay persons and clergy within the Catholic Church grievous concern surrounding the economic consequences following the rise of Latin American populist governments of the 1950s and 1960s - especially those of Perón in Argentina, Vargas in Brazil, and Cárdenas in Mexico. In failing to eradicate dependency, poverty and injustice, and carrying the burden of helping both to legitimate and reproduce the power and authority of the capitalist state for over five centuries, liberation theologians considered the Church an egregious failure in its mission to create the Kingdom of God, which they understood in the context of creating a just society on Earth, not some misty paradise beyond the pale of distant clouds, but a world in the here and now. Liberation theology, which coalesced into a movement throughout the 1960s and 1970s, attempted to establish the potential for a return of the role of the Church to the people (similar to the conditions that existed in earliest Christian communities) by nurturing criticalautonomous 'protagonistic agency' among the popular sectors, creating the conditions of possibility for consciousness-raising among peasants and proletarianised multitudes. (I recently coined the term protagonistic agency, to emphasize Freire's (1972) idea of being the subject of history rather than the object of history.)

PJ: This seems like a very Freirean agenda, Peter... Please outline Freire's influence on liberation pedagogy in more detail.

PM: Theologian William Herzog II is roundly critical of literary-critical readings of the parables of Jesus, especially their focus on narrativity and metaphoricity, their literary forms and parabolic and paradoxical aspects, which often results in "forcing the reader to reinterpret the meaning of interpretation itself" (1994: 13). In such readings, the parable "was being moved from the world...[and]...being situated most comfortably in the world of the interpreter" (ibid.). In contrast to literary critical readings, Herzog approves of comparing the parables of Jesus with the quest for the historical Jesus, and he approaches the understanding of Jesus' parables through the work of Paulo Freire especially Freire's approach to critical consciousness. Herzog writes:

In addition to their obvious differences, Jesus and Paulo have some things in common. Both figures worked with poor and oppressed peoples, and both worked with peasants. Although Freire's work with urban laborers 
has no counterpart in Jesus' public activity, their peasant audiences are similar (...) Both figures labored in societies that had been deformed by colonial exploitation whose presence continued to shape the life of its inhabitants. (ibid.: 25)

Herzog examines the similarities faced by the peasants to whom Jesus' parables spoke, and Freire's own students. He writes:

Freire was clearly focused on the twin tasks of teaching literacy and social analysis. But what about Jesus? Taking a cue from Freire, one may propose that Jesus' parables dealt with issues of interest to his "students." Their social scenes are therefore important for what they tell us of the world in which the peasants and rural underclass lived. To use Freire's language, they encode generative themes and objectify conditions of oppression so that they can be examined. All of this implies that some of the parables function in a manner similar to what Freire calls "codifications." They re-present a familiar or typified scene for the purpose of generating conversation about it and stimulating the kind of reflection that expose contradictions in popularly held beliefs or traditional thinking. (ibid.: 26)

There was another point of similarity between Jesus and Freire. According to Herzog, "[b]oth men were considered politically subversive, and both suffered political consequences because of their work" (ibid.: 27). Freire was imprisoned in Brazil and later was forced into self-exile. Jesus "was crucified between two 'social bandits'... on the charge of subversion because he claimed to be 'king of the Jews' (ibid.: 27). According to Herzog, “[w]ithout invoking the entire program developed by Freire, it is possible to propose that Jesus used parables to present situations familiar to the rural poor, to encode the systems of oppression that controlled their lives and held them in bondage" (ibid.: 27). Jesus, who lived in an oral culture, used storytelling; living in a visual culture, Freire used pictures as codifications. Herzog has appropriated Freire's methods of creating generative words, leading to codifications, then to decoding, problematizing and recodifying, using vocabulary and phonetic cards right up to the postliteracy phase to analyze the parables that appear in the Bible. In the final phase of Freire's literacy campaign, generative words were gathered "in an effort to identify the thematic universe they revealed" (ibid.: 23). According to Herzog,

[E]very historical epoch is marked by large themes, and people participate in their historical eras to the degree that they identify, shape, create, and recreate those themes. Passive spectators of history live by the themes determined by others, who in turn define their lives and limits. The failure to perceive and participate in the naming of epoch-making themes leads to 
a withdrawal from history as well as an abdication of the responsibility to remake history. Every such retreat ends in hopelessness. The generative themes of any era define its aspirations and the impediments that would repress their fulfillment and name the tasks that must be undertaken to realize those aspirations. Every exploration of a generative theme, then, involves interpreters more deeply in their new role as subjects capable of comprehending their world and translating their newly constituted knowledge into programs of action. The mystified illiterates became critical-thinking readers of their world. (ibid.: 23-24)

PJ: A similar focus on the poor is also present in the works of Karl Marx. However, Freire was a Christian believer, while Marx famously proclaimed religion as "the opium of the people" (Marx, 1970 [1843]). Your liberation theology is deeply situated in both traditions, and Pedagogy of Insurrection (McLaren, 2015) clearly leans towards the Latin American approach that sees Christianity as compatible with, and even beneficial to, revolutionary critical pedagogy. What are the reasons behind such direction of development of your thought?

PM: Freire has addressed the role of theologians and the Church - its formalism, supposed neutrality, and captivity in a complex web of bureaucratic rites that pretends to serve the oppressed but actually supports the power elite from the perspective of the philosophy of praxis that he developed throughout his life. For Freire, critical consciousness (conscientization) cannot be divorced from Christian consciousness. Freire's attack on bourgeois subjective idealism as "naïve consciousness" approaches the transformation of consciousness as a political act: to speak a true word, according to Freire, is to transform the world. The ruling class, from Freire's perspective, views consciousness as something that can be transformed by "lessons, lectures and eloquent sermons" (1973: 2). In this instance consciousness is essentially static, necrophilic (deathloving) as distinct from biophilic (life-loving), constitutes "an uncritical adherence to the ruling class" (1973: 2), and serves as a means of "emptying conscientization of its dialectical content" (1973: 3).

Freire calls for a type of class suicide in which the bourgeoisie take on a new apprenticeship of dying to their own class interests and experiencing their own Easter moment through a form of mutual understanding and transcendence. Freire argues that the theologians of Latin America must move forward and transform the dominant class interests in the interests of the suffering poor "if they are to experience 'death' as an oppressed class and be born again to liberation'” (1973: 6). Or else, they will be implicated within a Church "which forbids itself the Easter which it preaches" (1973: 5-6). Freire borrowed the concept of "class suicide" from Amilcar Cabral, the Guinea-Bissauan and Cape Verdean revolutionary and political leader who was assassinated in 1973. For Freire, insight into the conditions of social injustice of this world stipulates that 
the privileged must commit a type of "class suicide" where they self-consciously attempt to divest themselves of their power and privilege and willingly commit themselves to unlearning their attachment to their own self-interest. Essentially, this was a type of Easter experience in which a person willingly sacrifices his or her middle or ruling class interests in order to be reborn through a personal commitment to suffering alongside the poor.

Of course, this class suicide takes place in the context of a larger mission to end the social sin of poverty itself. It is a transformational process in which a person identifies with the poor and the oppressed and commits oneself to taking down all victims from the cross. Here we find an echo of the teachings of St Francis. Both Freire and St Francis understood that a transcendence of oppression - a striving upwards - in the struggle for liberation was not enough. As Leonardo Boff notes in his study of St Francis (1982), a striving "upwards" away from the travails of the world through the attainment of a mystical consciousness is not enough. What is also needed, and even more so, is a "transdescendence" - a kenotic act of selfemptying, an openness to the lives of those below - the poor, the stigmatized, the despised - and a willingness to integrate them into a community of love, kindness, and solidarity - a fraternal solidarity with those suffering from the scourge of life's deprivations. Christ encountered such trans-descendence in the wretched of the earth, in the crucified of history.

PJ: In theory, the concept of class suicide somehow seems much more viable than in practice ... How can we move on from theory to praxis?

PM: Let us examine some of Freire's positions here. Freire writes that the praxis by which consciousness is changed "is not only action but action and reflection" (1973: 3). He argues that theoretic praxis is only authentic when it maintains the dialectical movement between itself and the contextual specificity of the praxis one wishes to carry out, that is, when it is cognizant of the unity between practice and theory in which both are constructed, shaped, and reshaped. Authentic praxis, in other words, is a "dialectical movement which relates critical reflection on past action to the continuing struggle" (ibid.). For Freire, a pedagogy of liberation involves "social praxis" that is all about "helping to free human beings from the oppression which strangles them in their objective reality" (ibid.: 4). Social praxis, as explained by Freire, is what drew me to the Latin American tradition of liberation theology, a theology that encourages the oppressed to create and recreate themselves in history in a concrete fashion rather than participate in what Freire calls "a reformed repetition of the present" (ibid.). Freire writes:

I cannot permit myself to be a mere spectator. On the contrary, I must demand my place in the process of change. So the dramatic tension between the past and the future, death and life, being and non-being, is not longer a kind of dead-end for me; I can see it for what it really is: a permanent challenge to which I must respond. And my response can be 
none other than my historical praxis - in other words, revolutionary praxis. (ibid.: 7)

\section{The prophetic Church of Paulo Freire}

PJ: In the article 'Education, Liberation and The Church' (Freire, 1973), Freire analyses the three main types of church: the traditionalist, the modernizing, and the prophetic church. These days, when Pope Francis fights a battle of epic proportions against conservative fractions in the Catholic Church, Freire's analysis seems particularly interesting. What kind of Church would provide the best fit for liberation theology as you see it?

PM: Nita Freire, Paulo's widow, can be quoted to help illuminate an answer your question. In an interview with James Kirylo, Nita writes that

Paulo was a man of authentic faith that believed in God. And while he was Catholic, he was not caught up in the "religiosity" of the faith. He believed in Jesus Christ, and in His kindness, wisdom, and goodness. He did, however, have grave concerns with the Church, particularly the contradictions of its actions, and the actions of the priests. For example, he observed, since his childhood, how so many priests ate well and gained weight, yet the poor remained poor and hungry, only to hear the priests say to them, "Don't worry, God is with you, and your reward is great in heaven.” For Paulo, many priests, with their belly full, did not have authentic compassion and empathy for the poor, and were not consistent with what they had said and what they did. (Kirylo, 2011: 278).

Nita also mentions Paulo's work on the distinctions among the Church. She notes that

When Gustavo Gutierrez invited Paulo to work on some components related to liberation theology, Paulo began to analyze the distinct differences among what he called the traditional church, modern church, and the prophetic church. The prophetic church is one that gives witness and is a liberated church, one that "feels" with you; one that is in solidarity with you, with all the oppressed in the world, the exploited ones, and ones that are victimized by a capitalist society. (ibid.: 278)

Given Nita's insights, the most significant aspect of Freire's work on the different roles of the church, at least as it pertains to the context of the revolutionary critical pedagogy developed in my own work, would be what Paulo refers to as the prophetic church. This captures much of the spirit of José Porfirio Miranda's work in liberation theology, and the work of Jon Sobrino, Leonardo Boff, Gustavo Gutiérrez, James Cone, and many others. It certainly captures the spirit of the Reverend Martin Luther King. There is a 1989 American biopic depicting the story of Salvadoran Archbishop Óscar Romero 
(played by actor Raúl Juliá), who was assassinated while saying mass in 1980, having begun to organize non-violent resistance to the brutal Salvadorian military dictatorship. I show Romero (Duigan, 1989) to my students because it depicts priests who represent the traditional, modern, and prophetic church. The focus of the film is on the transformation undergone by Romero from being a supporter of the traditional church, with an acceptance of its modernizing aspects, to affirming the importance of the prophetic church, as he confronts the violence of El Salvador's civil war, and the "conscientização" or consciousness raising of some of his priests.

Romero (Duigan, 1989) shows how the prophetic church grew out of the contradictions embedded with social relations of production, relations supported by government corruption, the exploitation of the poor, and class war that exploded within a brutal comprador capitalist system (a system where local elites work on behalf of foreign governments in return for a share of the profits). It was the members of the prophetic church that risked their lives for the sake of the well-being of the poor, the exploited, those who were the targets of a brutal military regime. But the prophetic church is at work in every community where faith, solidarity and struggle is conjugated with hope for a better world. Here we need to remember the words of Dom Hélder Câmara, a Brazilian Roman Catholic Archbishop of Olinda and Recife, who had a profound influence on Freire: "When I give food to the poor, they call me a saint. When I ask why the poor have no food, they call me a communist" (in Rocha, 2000: 53).

PJ: The prophetic church is about the dialectics between being and becoming that Freire understood so well... as Zapatistas would say, we make the road by walking. Can you say a bit more about Freire's insights into this dialectic?

PM: It is not difficult to become depressed and drowned in cynicism given the state of the current historical conjuncture. Freire always reminded us to take stock of possibilities for liberation enfolded in current historical conditions. Today poses a special challenge. The revolting infection of capitalism and its implacable steel cast culture of unbridled viciousness that we know as austerity capitalism has devastated the soil of humanity, creating armies of weary and dispirited victims oscillating between hopelessness, futile gestures of defiance and unfounded acts of optimism. Arguments claiming the indisputable equivalence between capitalism and democracy have become all but superfluous today, revealed as a bitterly vehement propaganda ruse, as waves of immigrants lucky to survive the vortex of terror in their own war-torn native countries arrive via some miracle of discipline and focused desperation, at the gates of their vastly more prosperous neighbors. Many of them are sent back to face again the merciless torrents of war or conditions of austerity sure to increase their privations at a colossal scale. Hamstrung by the dogged defenders of white supremacy, remorseless outbreaks of nationalism, as well as scathing spectacles of indifference, those seeking refuge headed back into the abyss, 
victims of appalling attrition, casualties of the ghastly struggle for capitalist accumulation at a time when capitalism, inflated by its own success, has already passed its high water mark. Alternatives to capitalism might as well be forbidden, as socialism and communism have become so unremittingly condemned for decades, that any thought of rehabilitation is now considered unthinkable.

As a Marxist humanist social justice educator, it is imperative that we work towards the creation of a social universe absent of the value form of labor. What I admire so much about Freire is that he has been a staunch opponent of capitalism, aggravating the hegemony of this unstoppable colossus. He has picked apart the fallacious reasoning of the dung masters of colonialism. He refuses to disfigure what we have arrived at through our imagination, yet at the same time is at pains to engage in a dialectics of the concrete. He has brought down the curtain on the hypocrisy of bourgeois progressivists whose advocacy for the poor remains but as an advertisement for themselves. Paulo's generosity in response to my work gave me confidence. As a young scholar and activist in the mid 1980s, I admired how he was able to live an exemplary life. He displayed an independence of mind that did not fit easily into prevailing orthodoxies surrounding pedagogy. Freire understood that building a new society required not only material conditions but a utopian imagination, a living theory that mediated possibilities buried in actualities.

PJ: In a recent book chapter I wrote: "Revolutionary critical pedagogy respects its teachers, but does not create idols - as a live struggle, it constantly questions and reinvents its main figures and their works" (Jandrić, 2018: 199). Which aspect of Freire's work should we reinvent in and for the moment here and now? How should we go about it?

PM: There is no unimpeachable justification for regarding certain individuals as iconic figures - since there is a danger in being susceptible to the thrall of charismatic figures through the cult of personality. Yet there was something profoundly and earnestly iconic in the way that Paulo practiced the path which he exhorted others to follow, and a generosity of spirit that animated his relationships with others. Paulo's own unslakable thirst for learning and deepening his understanding of social life, was guided by a humility born of his own early experiences of hardship and a commitment to create the conditions of possibility for justice through dialogue - a dialogue that actively illuminated the internal contradictions of society, contradictions which, sadly, induce many of us through the sheer force of despair to underestimate the importance of struggle at every level of society. Such struggle stands under the scrutiny of its valiant history of political activism, of which Paulo played an important role. He was a materialist and a Catholic but he did not have an ideological belief in materialism and this helped to open the door to a form of utopianism, one which often bore the brunt of derision from some of his fellow philosophers, very often 
economistic Marxists. I saw his utopianism as critical to his work - which displayed a union of objectivity and subjectivity.

Paulo's understanding of the future was one that refused to ignore the difficulties of living everyday life in the capitalist present. Paulo's utopianism did not pull a veil over the challenges offered by the present. His was a concrete utopianism grounded in the struggle of everyday life, in a manner similar to the way Ernst Bloch treated the topic - that we can get glimpses of the future by examining the contradictions of the present. Of course, there is also a danger of utopianism being appropriated by fascism, of which Bloch was acutely aware. Today, there are currents of this appropriation in Trump's mission to "Make America Great Again" which prefigures a mythical past of an ideal society where white men were in control of all aspects of their lives. Marx's work was important in the way that it brought together a critique of political economy in the world dominated by capitalism and visions that were popular among utopian socialist movements who based their understanding of everyday life on what was lacking - triggering ideas for addressing the injustice in such a lack in the material conditions that mediated everyday life - making utopia context-specific to the contradictions in which people were living, yet at the same time providing the conditions for a universal vision for what a just society could look like.

\section{References}

Boff, L. (1982). Francis of Assisi: A Model of Human Liberation. Trans. J. W. Diercksmeier. Maryknoll, NY: Orbis Books

Brown, C. (1987). Literacy in 30 Hours: Paulo Freire's Process in Northeast Brazil. In I. Shor (Ed.)., Freire for the Classroom: A Sourcebook for Liberatory Teaching. Portsmouth, N.H.: Boynton/Cook, 215-231.

Duigan, J. (1989). Romero. [Motion picture]. Los Angeles: Warner Bros.

Ford, D. R. (2017). Education and the Production of Space: Political Pedagogy, Geography, and Urban Revolution. New York: Routledge.

Freeman, M. (1998). Mythical Time, Historical Time, and Narrative Fabric of the Self. Narrative Inquiry, 8(1), 27-50.

Freire, P. (1970). Cultural Action for Freedom. Cambridge, MA: Harvard Educational Review.

Freire, P. (1972). Pedagogy of the Oppressed. Harmondsworth: Penguin Education Specials.

Freire, P. (1973). Education, liberation and the Church. Study Encounter, 9(1): $1-16$.

Freire, P. (1978). Pedagogy in Process: Letters to Guinea-Bissau. New York: The Seabury Press.

Freire, P. (1985). The politics of education: Culture, power, and liberation. New York, NY: Bergin \& Garvey.

Freire, P. (1995). Preface. In: P. McLaren (Ed.). Critical Pedagogy and Predatory Culture. London: Routledge, pp.ix-xi. 
Gadotti, M. (1994). Reading Paulo Freire: His Life and Work. Albany, N.Y.: State University of New York Press.

Green. E. (2016). What are the most-cited publications in the social sciences (according to Google Scholar)?. Accessed January 3, 2018. http://blogs.lse.ac.uk/impactofsocialsciences/2016/05/12/what-are-the-mostcited-publications-in-the-social-sciences-according-to-google-scholar/.

Herzog, W. (1994). Parables as Subversive Speech: Jesus as Pedagogue of the Oppressed. Louisville, Kentucky: Westminster John Knox Press.

Jandrić, P. (2017). Learning in the Age of Digital Reason. Rotterdam: Sense.

Jandrić, P. (2018). The challenge of the internationalist critical pedagogue. In McLaren, P. \& Soohoo, S. (Eds.), Radical Imagine-Nation: Public Pedagogy \& Praxis. New York: Peter Lang, 199-211.

Kirylo, J. D. (2011). Paulo Freire: The Man from Recife. New York: Peter Lang.

Marx, K. (1970 [1843]). Critique of Hegel's Philosophy of Right. Trans. A. Jolin and J. O’Malley. Cambridge: Cambridge University Press.

McLaren, P. \& Jandrić, P. (2014). Critical revolutionary pedagogy is made by walking - in a world where many worlds coexist. Policy Futures in Education, 12(6), 805-831.

McLaren, P. \& Jandrić, P. (2015a). The critical challenge of networked learning: using information technologies in the service of humanity. In Petar Jandrić \& Damir Boras (Eds.), Critical Learning in Digital Networks. New York: Springer.

McLaren, P. \& Jandrić, P. (2015b). Revolutionary critical pedagogy is made by walking - in a world where many worlds coexist. In P. McLaren, Pedagogy of Insurrection: From Resurrection to Revolution. New York: Peter Lang, 255298.

McLaren, P. \& Jandrić, P. (2017a). From Liberation to Salvation: Revolutionary critical pedagogy meets liberation theology. Policy Futures in Education, 15(5), 620-652.

McLaren, P. \& Jandrić, P. (2017b). Peter McLaren's Liberation Theology: Karl Marx meets Jesus Christ. In J. S. Brooks and A. Normore (Eds.), Leading Against the Grain: Lessons for Creating Just and Equitable Schools. New York: Teachers College Press, 39-48.

McLaren, P. \& Jandrić, P. (2018). Karl Marx and Liberation Theology: Dialectical materialism and Christian spirituality in, against, and beyond contemporary capitalism. TripleC: Communication, Capitalism \& Critique.

McLaren, P. (1989, $6^{\text {th }}$ edition 2014). Life in Schools: An Introduction to Critical Pedagogy in the Foundations of Education. New York and London: Longmans.

McLaren, P. (1997). Paulo Freire died May 2, 1997. International Journal of Educational Reform, 6(3): 263-256. 
McLaren, P. (2000). Che Guevara, Paulo Freire, and the pedagogy of revolution. Boulder, CO: Rowman \& Littlefield.

McLaren, P. (2011). Afterword: Paulo Freire: Defending His Heritage to Remake the Earth. In J. D. Kirylo, Paulo Freire: The Man from Recife. New York: Peter Lang, 305-320.

McLaren, P. (2015). Pedagogy of Insurrection: From Resurrection to Revolution. New York: Peter Lang.

Rocha, Z. (2000). Helder, O Dom: uma vida que marcou os rumos da Igreja no Brasil. Petrópolis (Brazil): Editora Vozes.

Stetsenko, A. (2002). Vygotsky's Cultural-Historical Activity Theory: Collaborative Practice and Knowledge Construction Process. In D. Robbins and A. Stetsenko, (Eds.), Vygotsky's Psychology: Voices from the Past and Present. New York: Nova Science Press.

Peter McLaren is a Distinguished Professor in Critical Studies at Chapman University, USA, where he is Co-Director of the Paulo Freire Democratic Project. Professor McLaren is the author and editor of nearly 50 books and hundreds of professional publications on education and social justice. His writings have been translated into over 20 languages. One of Professor McLaren's recent awards includes the Outstanding Educator in America Award presented to him by the Association of Educators of Latin America and the Caribbean.

Petar Jandrić is a Professor in Digital Learning and Programme Director of BSc (Informatics) at the Zagreb University of Applied Sciences (Croatia), and visiting Associate Professor at the University of Zagreb (Croatia). His research is focused to trans-disciplinary collaborations at the intersections between critical pedagogy and digital cultures. Petar published six books, dozens of scholarly articles and chapters, and numerous popular articles. His writings have been published in several languages. Personal website: http://petarjandric.com/. 